DEMOCRACY AND DIFFERENCE 



\section{DEMOCRACY AND DIFFERENCE}

CONTESTING THE BOUNDARIES

OF THE POLITICAL

Edited by Seyla Benhabib 
Copyright (C) 1996 by Princeton University Press

Published by Princeton University Press, 41 William Street,

Princeton, New Jersey 08540

In the United Kingdom: Princeton University Press,

Chichester, West Sussex

All Rights Reserved

\section{Library of Congress Cataloging-in-Publication Data}

Democracy and difference : Contesting the boundaries of the political / edited by Seyla Benhabib.

p. $\mathrm{cm}$.

Includes bibliographical references and index.

ISBN 0-691-04479-1 (cl : alk. paper).-

ISBN 0-691-04478-3 (pb : alk. paper)

1. Democracy. 2. Ethnicity. 3. Nationalism.

4. Social movements. I. Benhabib, Seyla.

JC423.D43979 1996

321.8-dc20 96-2189

This book has been composed in Berkeley Book

Princeton University Press books are printed on acid-free paper and meet the guidelines for permanence and durability of the Committee on Production Guidelines for Book Longevity of the Council on Library Resources

Printed in the United States of America by Princeton Academic Press

$\begin{array}{llllllll}10 & 9 & 8 & 7 & 6 & 5 & 4 & 3\end{array}$

ISBN-13: 978-0-691-04478-1 (pbk.) 